\title{
Building on "Traditional" Land Dispute Resolution Mechanisms in Rural Ghana: Adaptive or Anachronistic?
}

Festus A. Asaaga

Citation: Asaaga, F.A. Building on

"Traditional" Land Dispute

Resolution Mechanisms in Rural

Ghana: Adaptive or Anachronistic?

Land 2021, 10, 143. https://doi.org/

10.3390/land 10020143

Academic Editors:

Uchendu Eugene Chigbu,

Ruishan Chen and Chao Ye

Received: 6 January 2021

Accepted: 28 January 2021

Published: 2 February 202

Publisher's Note: MDPI stays neutral with regard to jurisdictional claims in published maps and institutional affiliations.

Copyright: (c) 2021 by the author Licensee MDPI, Basel, Switzerland. This article is an open access article distributed under the terms and conditions of the Creative Commons Attribution (CC BY) license (https:// creativecommons.org/licenses/by/ $4.0 /)$
UK Centre for Ecology and Hydrology, Maclean Building, Crowmarsh Gifford, Benson Lane, Wallingford, Oxfordshire OX10 8B, UK; fesasa@ceh.ac.uk or fasaaga@gmail.com

\begin{abstract}
Despite the ongoing land administration reforms being implemented across sub-Saharan Africa (SSA), including Ghana, as a viable pathway to achieve tenure security and greater efficiency in land administration, the subject of land dispute resolution has received relatively less attention. Whereas customary tenure institutions play a central role in land administration (controlling 80\% of all land in Ghana), they remain at the fringes of the formal land dispute adjudicatory process. Recognising the pivotal role of traditional institutions as development agents and potential vehicles for promoting good land governance, recent discourses on land tenure have geared toward mainstreaming traditional land dispute institutions into the architecture of the formal judicial process via alternative dispute resolution pathways. Yet, little is known, at least empirically, as to the operations of traditional dispute resolution institutions in the contemporary context. This study therefore explores the importance of traditional dispute resolution institutions in the management of land-related disputes in southcentral and western Ghana, drawing on data collated from 380 farming households operating 746 plots. The results show that contrary to the conventional thinking that traditional institutions are anachronistic and not fit for purpose, they remain strong and a preferred forum for land dispute resolution (proving resilient and adaptable), given the changing socio-economic and tenurial conditions. Yet, these forums have differing implications for different actors within the customary spheres accessing them. The results highlight practical ways for incorporating traditional dispute resolution in the overall land governance setup in Ghana and elsewhere in sub-Saharan Africa. This has implications for redesigning context-specific and appropriate land-use policy interventions that address local land dispute resolution.
\end{abstract}

Keywords: land dispute; customary land tenure; statutory land tenure; tenure security; Ghana; sub-Saharan Africa

\section{Introduction}

Over the past two decades or so, the good governance agenda has gained currency both in theory and in practice within the context of contemporary land management as a plausible strategy for navigating a sustainable development trajectory in the global South, particularly in sub-Saharan Africa (SSA) [1-3]. The promotion of the good land governance agenda has reinvigorated into the spotlight a raging debate on the land question regarding contextually relevant pathways to engender land tenure security and equitable customary land management in the SSA context [3-6]. Central to this emerging critical discourse is the enduring challenge of widespread customary land disputes exacerbated by the increasing commodification and individualisation of communal lands in most rural parts of SSA [7-9]. Although the wide-ranging socio-economic and political consequences of customary land disputes in affected areas and countries are well-documented in the literature [7,10], it is also acknowledged that the effects of customary land disputes vary across different spatial continuums, from rural to peri-urban to urban areas [7]. There is increasing evidence that rural and peri-urban areas in several SSA countries (including Ghana) have become contested zones in the light of the growing land commodification and large-scale commercial land acquisitions $[8,11,12]$. The interplay of such local-level 
land disputes and contestations poses several far-reaching developmental challenges considering the primacy of secure and equitable land access to the achievement of many of the Sustainable Development Goals (SGDs) in SSA countries [11,13].

Against this background, successive SSA governments (with support from the World Bank and other international development partners) have over time pursued Westernstyled individualised statutory land tenure as a panacea to the seemingly insurmountable problems of tenure insecurity and contestations over land ownership $[4,6,8]$. This has been predicated on the underlying logic that customary tenure institutions (although controlling about $80 \%$ of SSA's total land area [14]) are anachronistic and not fit for purpose in addressing contemporary tenurial challenges $[6,8,15,16]$. Advocates of this conceptual view highlight the ambiguity, uncertainty and looseness of customary tenure structures, which render them ineffective or weak in dealing with land disputes and tenure insecurity, necessitating formalisation $[17,18]$.

In spite of the great expectations that supplanting customary land tenure systems with Western-styled statutory tenure systems will afford greater certainty in land rights (tenure security and efficient dispute resolution mechanisms), and by extension economic development [19,20], the implementation outcomes in most parts of SSA (including Ghana) have, at best, been disappointing [21]. The under-performance of statutory systems has prompted many critics to question the suitability of the blanket pursuit of formalisation as a panacea to supposedly insecure customary land rights in the SSA context $[15,22,23]$. For instance, Bromley's [15] review suggested that formalisation in the SSA context has, in many instances, rather re-created and exacerbated existing land inequalities and contestations over land. While a few recent studies have reported some relative success of land titling intervention programs in SSA countries [24,25], altogether the available statistics still show far less achievement with respect to addressing problems of tenure insecurity and land disputes on a regional scale.

While the reasons for the failure of past land tenure reforms are complex and wideranging [16,21], a burgeoning critical scholarship expresses a strong optimism that customary tenure institutions, despite their imperfections, are still relevant and fit for purpose in the contemporary context, especially in under-served rural areas of SSA countries $[22,26,27]$. In other words, their arguments echo important contextual or place-based differences rather than universalist descriptions that shape and determine tenurial outcomes. Thus, given the right institutional tinkering or tenurial re-engineering of customary tenure institutions (which others have characterised as adaptation [28]), they are better positioned to deliver tenure security and respond to other emergent tenurial challenges $[5,9,22]$. In any event, an important take-home message from the two opposing conceptual positions rests on how customary tenure institutions fare [ing] on the ground in terms of safeguarding tenure security and, more particularly, effectively addressing land disputes across the sub-region [22,29]. Although a theoretical exposition is useful, a conclusive examination of this hypothesis is certainly an empirical matter.

Yet, to date, in spite of the renewed policy interest in customary tenure institutions, little is known, at least empirically, about the factors that have allowed them to withstand colonial and post-colonial reforms and retain their role in local-level land governance. With the notable exception of a few recent studies $[8,9,30,31]$, there is a relative dearth of empirical focus on the potential role of customary systems in the contemporary context, particularly with respect to land disputes and traditional dispute resolution pathways [32-34]. A more nuanced and detailed contextual understanding of the operations of customary tenure institutions and the limits of their adaptability remains critical to better inform and guide on-going and future interventions towards the integration of customary tenure systems into the formal statutory framework for improved tenure security and effective land dispute resolution [8,9]. As argued by Anyidoho et al. [35], the process of tenurial adaptation cannot happen in isolation from the historical, political and legal context, which change cannot be imposed but must be built upon the institutional structures and practices that have evolved over time. Cleaver [36] also observed that the effectiveness of tenurial 
interventions is predicated on a socially informed analysis of the content and effects of informal/customary institutional arrangements rather than their form alone.

From the foregoing considerations, three key questions beg answers, namely (1) why have traditional land dispute resolution institutions persisted, (2) are they still fit for purpose or relevant in contemporary land governance and (3) how can customary dispute resolution mechanisms be effectively integrated into the formal statutory framework across socio-spatial contexts? This paper seeks to address these questions by focusing on Ghana's context characterised by a pluralistic tenurial regime, which is currently undergoing a process of harmonisation to enhance tenure security and address land disputes as a point of departure. Synonymous to other SSA countries, Ghana initiated a 25-year land administration reform (LAR) in 2003 as a plausible developmental pathway to enhance tenure security and efficient land administration $[37,38]$. Central to the LAP agenda is streamlining of the disparate customary and statutory tenure structures for effective local-level land dispute resolution using the customary land secretariats as a key operational vehicle. Although this paper focusses on Ghana's context, the findings of the study are broadly relevant for other SSA countries with a similar tenurial context in providing useful lessons towards the effective implementation of land reforms to achieve beneficial outcomes.

The rest of this paper is structured as follows. The next section provides an overview of contemporary land governance in Ghana, particularly focusing on land disputes and resolution mechanisms to provide a contextual background to situate the subsequent empirical analysis. Section 3 discusses the methods and data used for the paper, followed by a discussion of the results on dynamics of land disputes and resolution pathways in Section 4 . The concluding aspect discusses the implications of the findings for integrating customary tenure arrangements into the statutory framework.

\section{Contemporary Hybrid Land Governance and Dispute Resolution in Ghana}

To sufficiently understand the contemporary debates about the hybridity of land governance in Ghana, it is instructive to consider the historical antecedents of land policies and interventions that have shaped the evolution of neo-customary tenure institutions in the country. Within this context, Ghana is characterised by a pluralistic legal framework consisting of customary and statutory law operationalised within a multi-sectoral governance environment $[37,39,40]$. Available statistics indicate that $78 \%$ of Ghana's total land is classified as customary land, with the remaining $22 \%$ falling under the domain of the state ( $20 \%$ exclusively owned by the state and $2 \%$ vested lands that are managed by the state but communally owned) $[8,41]$. The disparate customary and statutory tenure systems have developed over time and undergone several reforms to reach their present state today (for a detailed overview of Ghana's bifurcated tenurial system, see [22]).

While all prominent studies on Ghanaian land tenure [39,40,42] have underscored how customary law is formally recognised and remains an important body of law in all aspects of Ghana's society, the resolution of land disputes has traditionally been in statutory courts. Yet, evidence suggests that the formal court system is clogged with land-related disputes. Over time, increasing contestations regarding land ownership (which is rooted in the legacies of colonialisation; see [43,44]) has meant the introduction of several land policies and interventions by the colonial politico-administrative framework to restructure the supposedly inefficient and insecure customary tenure arrangements [40,45]. A flurry of post-independence legislations also operated to entrench Western-styled statutory tenure, resulting in the dualism of the land governance structures.

Dispute resolution over access to land resources is an important driver of locallevel tensions across sub-Saharan Africa, given the marked diversity in the socio-cultural, political and economic spheres [46,47]. Within this context, a critical aspect of the debate in Ghana and SSA generally is the inherent disconnect between customary and statutory tenure systems, which are poorly articulated and seem to be on a collision course $[39,40,48]$. As the tenurial system defines the conditions of access, use and control of land and its associated resources in a particular socio-political context, it also invariably underpins 
livelihood security and sustainable land use and management. Nonetheless, issues of inequities in access to and control of land, tenure insecurity and protracted land disputes are characteristic of Ghana's existing tenurial regime [37,49,50]. Within this purview, there seem to be little consensus on the importance of customary tenure arrangements and institutions in promoting equitable land management and sustainable development in general.

Synonymous to other SSA countries, contestations over land in Ghana are acute and insidious, permeating/far-reaching implications for socio-economic development [10]. The increasing commodification and individualisation of land are manifested in the growing land scarcity and disputation over land $[8,29]$. According to the National Land Policy [37], the causes of land-related disputes have been identified to include multiple sales of land. Whereas the advent of land disputes predates the colonial era, this period was a watershed moment, ushering the indirect rule that served to supplant local customary tenure institutions with statutory tenure. Recent attempts at the harmonisation have witnessed the recognition of customary tenure institutions as central in the effective resolution of land-related disputes, particularly at the local level operating in tandem with the formal state courts [10]. Central to this are debates about how to successfully harmonise the disparate customary and statutory tenure to promote efficiency, enhance the security of tenure and reduce disputes over land. Current debates in the literature revolve around two main issues: (1) whether customary tenure should be supported due to its inherent flexibility, social embeddedness and accessibility and whether it guarantees tenure security [10] and (2) customary tenure is anachronistic and does not adequately safeguard security due to its inherent power imbalances [8,29].

\section{Materials and Methods}

\subsection{Study Sites}

This paper is based on a larger DPhil study that examined the dynamics of land tenure and sustainable land management in Ghana [22]. The analysis presented is based on data collated from two study sites, Kakum and Ankasa Conservation Areas situated in the central and western regions of southern Ghana, respectively (see Figure 1). These landscapes are dominated by the permanently protected Kakum National Park and Ankasa National Park and surrounding communities, spanning a total area of $360 \mathrm{~km}^{2}$ and $509 \mathrm{~km}^{2}$, respectively. The research was conducted in 19 fringe communities randomly selected in Kakum and Ankasa between December 2013 and September 2015 (Figure 1). Aside from having similar tenurial and social contexts affording comparability, both study sites were selected because of their representativeness in illustrating and exploring the prevailing tenurial situation in Ghana's high-forest zone, which spans the southern third of Ghana. In this context, most of the land in the off-reserve areas is stool land wholly owned and managed by the traditional authorities, with pockets of farmlands owned on a leasehold basis (spanning 2 to 50 years) also present [8,22]. Cocoa, oil palm and food crop farming are the dominant economic activities undertaken by households on relatively smaller plots $(<5 \mathrm{ha})$ in the studied communities, working the land under diverse tenurial arrangements, ranging from customary freehold to customary licenses. The tenurial and ethnic diversity in the studied communities afforded a unique opportunity to explore how differences in socio-cultural dynamics (re-)shape tenurial outcomes and conditions of land rights in the study areas. 


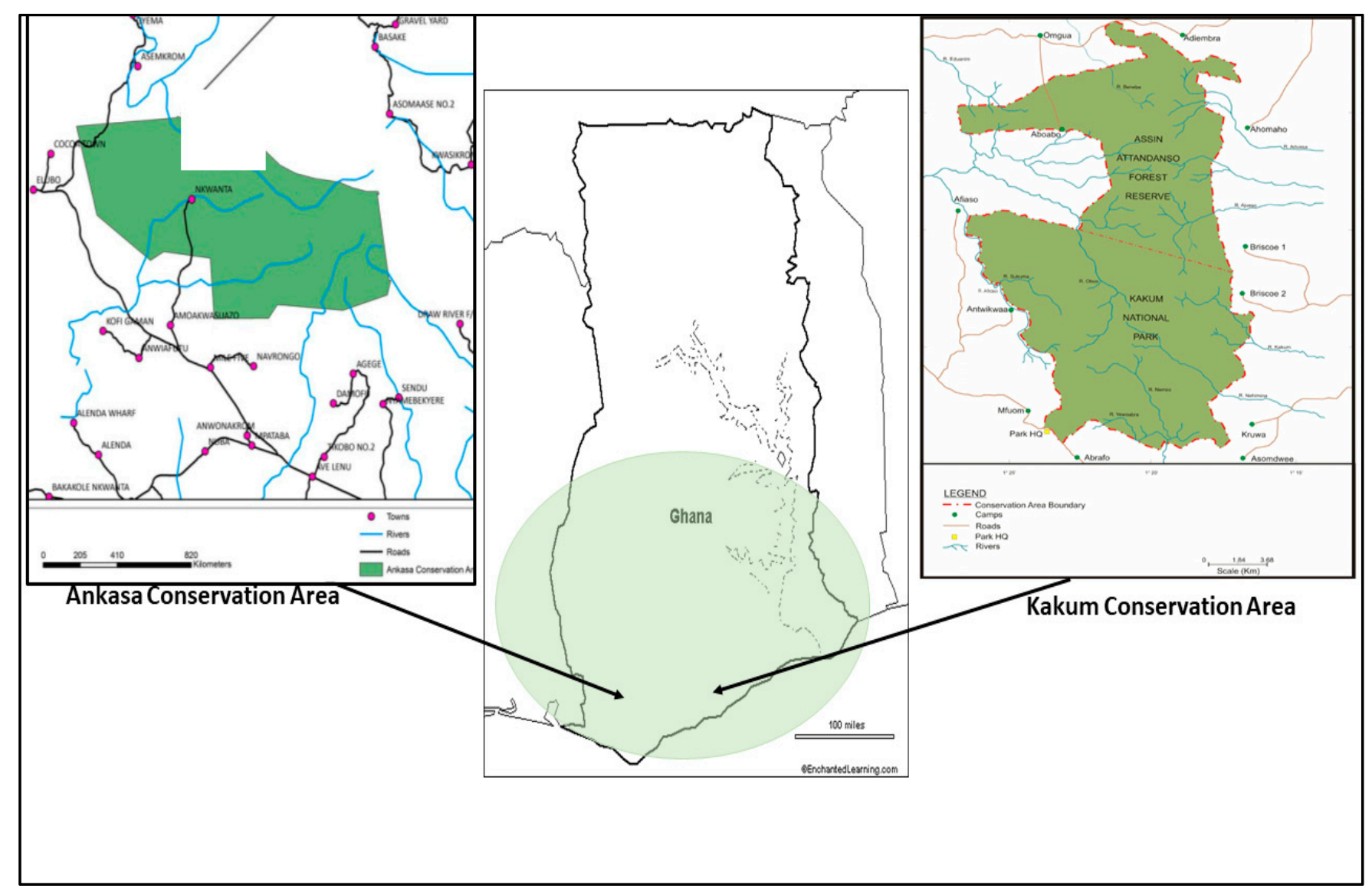

Figure 1. Overview of the two study sites in Ghana. The green area in the map of Ghana illustrates the high-forest zone, with left and right dark arrows pointing to the approximate locations of Ankasa and Kakum conservation areas in the south-western and central regions, respectively. Source: Based on Asaaga and Hirons [8].

\subsection{Methods}

Within the sampled villages, farming households were selected using stratified random sampling based on the gender and ethnicity of the household head, yielding a total sample size of 380 households $^{1}$ (Kakum, $n=232$; Ankasa, $n=148$ ). The rationale for sampling the households along gender and ethnicity lines was to ensure that the study sufficiently captures important tenurial differences that exist within and across social groups in the study context $[8,22,27,29]$. In this regard, the majority of households surveyed were (320, or $84 \%$ ) male-headed, reflecting the dominance of men in land-use decision-making, even in matrilineal contexts. To the extent that women dominate agriculture in Ghana, this suggests that the seemingly gender-disproportionate sample could be a limitation of this study $[8,22]$. Nevertheless, the careful constitution of the focus groups vis-à-vis the treatment of gender as an analytical category in this study afforded in-depth qualitative insights into the key differences between men and women regarding perceptions and experiences with local dispute resolution mechanisms.

The administered household surveys were supplemented with focus group interviews (in 8 communities), with farmers purposively selected for their in-depth knowledge of the communities, and key informant interviews with farmers, traditional authorities, farmer cooperative representatives and selected local- and national-level officials of key land sector agencies (including from the Assinman Customary Land Secretariat (CLS), Office

1 In instances where some household members managed their landholdings independently, they were also interviewed to capture specific variations in tenurial dynamics. This approach afforded an opportunity to capture the views of such household members (particularly female plot managers within male-headed households) who otherwise would have been excluded. 
of the Administrator of Stool Lands (OASL) and Ghana National Land Administration Project Secretariat), which afforded an opportunity to sufficiently explain and capture some local-level nuances on tenurial dynamics, which otherwise would have been difficult to capture in a wholly quantitative study. The semi-structured interviews with the key stakeholders in customary land management conducted in $\mathrm{Twi}^{2}$ focused on collating information on the prevailing tenurial situation in the studied communities, perceptions about land tenure security, land disputes and mechanisms for safeguarding land rights among others. The collated interview data from the semi-structured interviews and Focus Group Discussions (FGDs) were transcribed, followed by content and thematic analysis of the ensuing textual data guided by Miles and Huberman's [51] general strategy for qualitative analysis. The survey data were coded, entered, cross-checked for accuracy and analysed using SPSS (version 20). Cross-tabulation analysis and Pearson's chi-square tests were performed to detect significant differences $(p<0.05)$ between groups based on study area, gender and ethnicity. A dispute perception score was developed to ascertain the severity of land-related disputes in the studied communities. Using a five-point Likert scale, the opinions of respondents were measured by assigning a weight of 5 if 'they felt land disputes are a very serious problem', 4 if 'they felt land disputes are a serious problem,' 3 if 'they were uncertain,' 2 if 'they felt land disputes are somewhat not a problem' and 1 if 'they felt land disputes are not at all a problem'. Therefore, a high score above the median score meant a positive perception to the statement (i.e., severity of land disputes in a said community) and vice-versa. It was assumed that respondents who were uncertain as to whether land-related disputes are problematic in their communities would have a median score, which in this case is 3 . The final (mean) score represents the cumulative perception of respondents on a particular statement of the severity of land-related disputes in the surveyed communities.

\section{Results and Discussion}

This section describes the results based on households' perceptions and experiences about land dispute resolution in the context of the study areas. First, the pattern of land disputes is presented, followed by the different landholders' experiences and perceptions regarding land dispute resolution pathways. Drawing on these findings, the contemporary role of customary land dispute resolution institutions is then discussed, highlighting the challenges and opportunities for integration into the statutory framework towards bolstering local tenure security and equitable land management.

\subsection{Patterns of Land Disputes in Ankasa and Kakum}

The changing context of customary tenure relations exemplified by widespread monetisation and exclusions in the Ankasa and Kakum regions have been described elsewhere [8]. Within this context of evolutionary changes in customary tenure dynamics, it was pertinent to understand the patterns of emerging land-related disputes and stakeholders' perceptions, as manifested in the study areas ${ }^{3}$. Thus, on the question of whether the surveyed communities had experienced any disputes within the last five years, it appears from the survey data that land-related disputes were more pronounced in the Kakum context. Of the 232 respondents interviewed in Kakum, 60\% confirmed the prevalence of landrelated disputes in their respective communities relative to just $28 \%$ (or 41 respondents) who alluded to same in Ankasa. To further ascertain the extent to which land disputes were problematic, the respondents' views were solicited based on five-point Likert scale measurement (ranging from not a problem to a serious problem), as shown in Table 1.

2 Twi is the most widely spoken language amongst the Akan tribal groupings of southern Ghana.

3 Recognising the sensitivity of land issues and the tendency for respondents to either exaggerate or withhold information about the subject, care was taken when soliciting respondents' views on the incidence of land-related disputes in their respective communities. The question was approached from different angles to ascertain the factual situation on the ground. 
Table 1. Severity of land disputes in the surveyed communities.

\begin{tabular}{|c|c|c|c|c|c|}
\hline \multirow[t]{2}{*}{ Statement } & \multicolumn{2}{|c|}{ Severity of Land Disputes } & \multirow[t]{2}{*}{ Statement } & \multicolumn{2}{|c|}{ Severity of Land Disputes } \\
\hline & Responses & Mean Score & & Responses & Mean Score ${ }^{4}$ \\
\hline Totoda & 30 & 4.33 & Kusasi & 10 & 2.10 \\
\hline Fante & 20 & 3.95 & Navrongo & 18 & 3.06 \\
\hline Jerusalem & 12 & 4.83 & Nyamebekyere & 23 & 2.74 \\
\hline Nkwantannan & 24 & 3.88 & Kanokware & 20 & 3.30 \\
\hline Kwame-Anang & 11 & 4.00 & Fawoman & 22 & 3.45 \\
\hline Appiahkrom & 26 & 3.54 & Amokwaosuazo & 20 & 3.45 \\
\hline Nkwanta & 11 & 3.00 & Ghana-Nungua & 20 & 3.45 \\
\hline Mankata & 21 & 3.81 & Old Ankasa & 15 & 3.27 \\
\hline Bunsu & 42 & 3.79 & Total $(N)$ & 148 & 3.16 \\
\hline Seidukrom & 25 & 2.96 & & & \\
\hline Kwaku-Mmore & 10 & 3.10 & & & \\
\hline Total $(N)$ & 232 & 3.72 & & & \\
\hline
\end{tabular}

It is quite clear from Table 1 that land disputes were prevalent in almost all the surveyed communities in Kakum, except for Seidukrom, Nkwanta and Kwaku-Mmore, which appeared to be the least problematic relative to the other communities. Juxtaposing to Ankasa' s context, a similar pattern is discernible across all the studied communities except for Kusasi and Nyamebekyere, which portrayed a negative perception to the above statement, with mean community scores of 2.10 and 2.74, respectively (less than the median value of 3). It can therefore be suggested that the incidence of land disputes appeared to be very problematic in the communities with high land scarcity, particularly in the Kakum area (e.g., Totoda, Kwame-Anang). This, in a way, highlights the growing tensions and/or disputes with regards to land access, with potentially negative implications for the security of land rights of some local landholders. Paradoxically, research and policy emphasis seem to be devoted to violent and large-scale disputes to the relative neglect of small-scale looming disputes, which have the propensity to escalate into full-blown large-scale disputes [52]. From the FGDs, participants expressed the view that disputes associated with land use created situations of uncertainty and insecurity about land rights. The foregoing analysis begs a typical question as to the nature of such intra-community disputes experienced in the study areas. Figure 2 therefore typifies the nature of landrelated disputes, as evidenced in the surveyed communities.

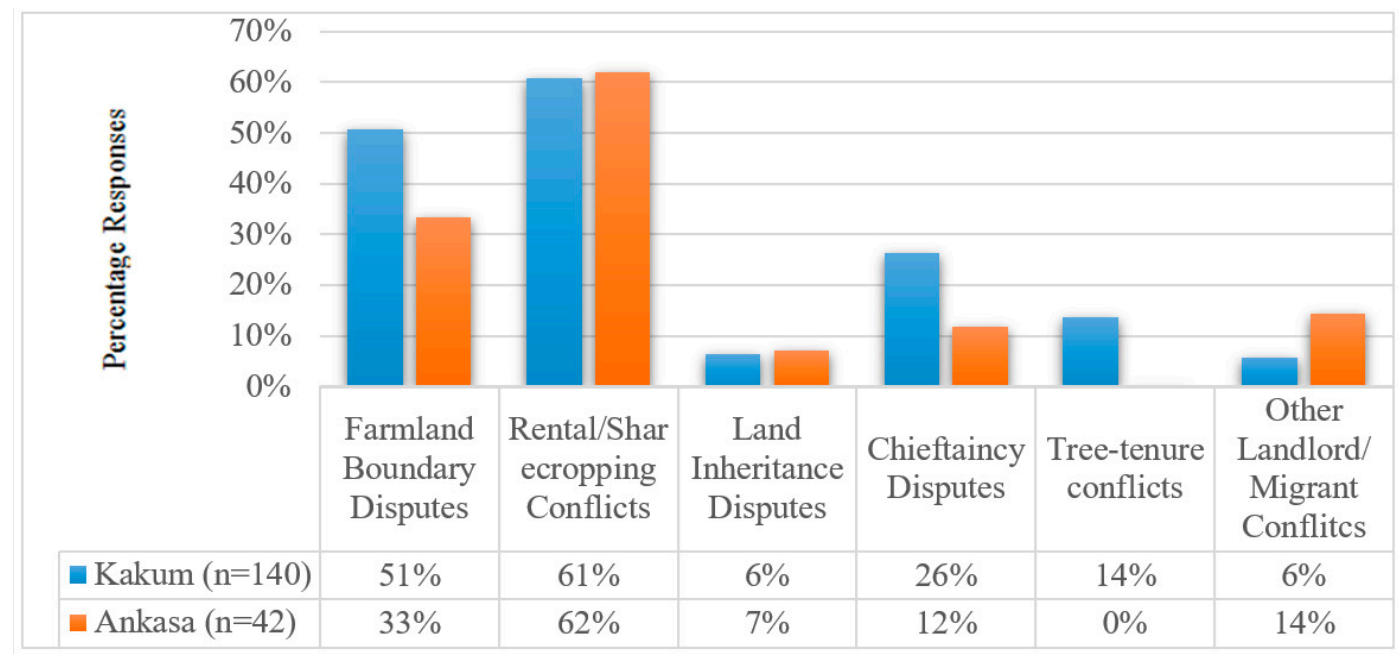

Figure 2. Type of land disputes in the study areas. Figure based on multiple responses on the nature of land disputes.

4 The mean scores of communities were computed by aggregating individual responses to the statement divided by the total number of respondents surveyed in the respective communities. 
As can be seen from Figure 2, sharecropping disputes constituted the commonest form of land-related disputes across the two case study regions. It was gathered from the key informant interviews that the incidence of land rental/sharecropping disputes was attributable to the oral, open-ended and variable nature of terms and conditions of the grant, which renders them highly susceptible to disputes. Generally, while most interviewees downplayed the seriousness of land disputes at the community level, focused and key-informant interviews showed that the impact of land-related disputes at the community level is very far-reaching, with negative consequences for tenure security and access arrangements.

\subsection{Household Experiences of Land-Related Disputes: A Plot-Level Analysis}

To further explore the dynamics of land-related disputes at the household level, a question was asked as to whether respondents had experienced disputes pertaining to their landholdings. As discernible from Table 2, whereas a breach of sharecropping terms was the common form of land-related disputes in Kakum, farmland boundary disputes were more prevalent in Ankasa. In general, the oral nature of most sharecropping contracts and indeterminate land boundaries have been noted as the common causes of land-related disputes amongst land users in rural Ghana $[37,53,54]$. Yet, the inherent flexibility in the execution of oral grants in addition to being convenient channels for maintaining social cohesion are some positive attributes, which perhaps explains their pervasive practice across rural communities in Ghana.

Table 2. Experience of previous disputes over household plots (\%).

\begin{tabular}{|c|c|c|c|c|}
\hline \multirow{3}{*}{ Have You Had a Dispute with Anyone Over This Plot? } & \multirow{2}{*}{\multicolumn{2}{|c|}{$\begin{array}{c}\text { Kakum Region } \\
\text { Household Plots }\end{array}$}} & \multirow{2}{*}{\multicolumn{2}{|c|}{$\begin{array}{c}\text { Ankasa Region } \\
\text { Household Plots }\end{array}$}} \\
\hline & & & & \\
\hline & Indigene & Migrant & Indigene & Migrant \\
\hline Yes & $14 \%$ & $14 \%$ & $10 \%$ & $12 \%$ \\
\hline No & $86 \%$ & $86 \%$ & $90 \%$ & $88 \%$ \\
\hline Total & $(n=29)$ & $(n=491)$ & $(n=73)$ & $(n=170)$ \\
\hline \multicolumn{5}{|l|}{ Specific nature of the dispute } \\
\hline Farmland boundary disputes & $50 \%$ & $17 \%$ & $43 \%$ & $60 \%$ \\
\hline Multiple claims to land & $0 \%$ & $19 \%$ & $43 \%$ & $20 \%$ \\
\hline Breach of terms (sharecropping) & $50 \%$ & $60 \%$ & $14 \%$ & $20 \%$ \\
\hline Tree-tenure disputes & 0 & 0 & 0 & 0 \\
\hline Other landlord-migrant disputes & 0 & $4 \%$ & 0 & 0 \\
\hline Total & $(n=4)$ & $(n=69)$ & $(n=7)$ & $(n=20)$ \\
\hline
\end{tabular}

The incidence of land-related disputes perhaps gives more impetus to the respondents quest to protect and secure their property rights. Yet, information from key informants and FGDs indicates that there was the underlying tendency of bias in favour of indigenes, especially in instances of disputes involving migrants and their indigenous landlords. Moreover, groups of people with strong socio-political connections within the community stood a better chance of securing a favourable judgement in the event of disputes over land. This invariably creates room for some level of uncertainty as to the adequate protection and legitimacy of land rights of different social groups. The succeeding section therefore examines in more detail the local mechanisms for land dispute resolution in the study areas. Preceding this is a discussion on the common boundary indicators used in household plot identification in the light of the prevalence of farmland boundary disputes as mentioned above.

Nature of Farmland Boundary Indicators of Household Plots

In view of the relatively high incidence of farmland boundary disputes (especially in Ankasa), respondents were asked about the specific boundary indicators of their respective 
household landholdings as a way of identifying plausible factors occasioning such disputes (and insecurity) over land, as shown in Figure 3.

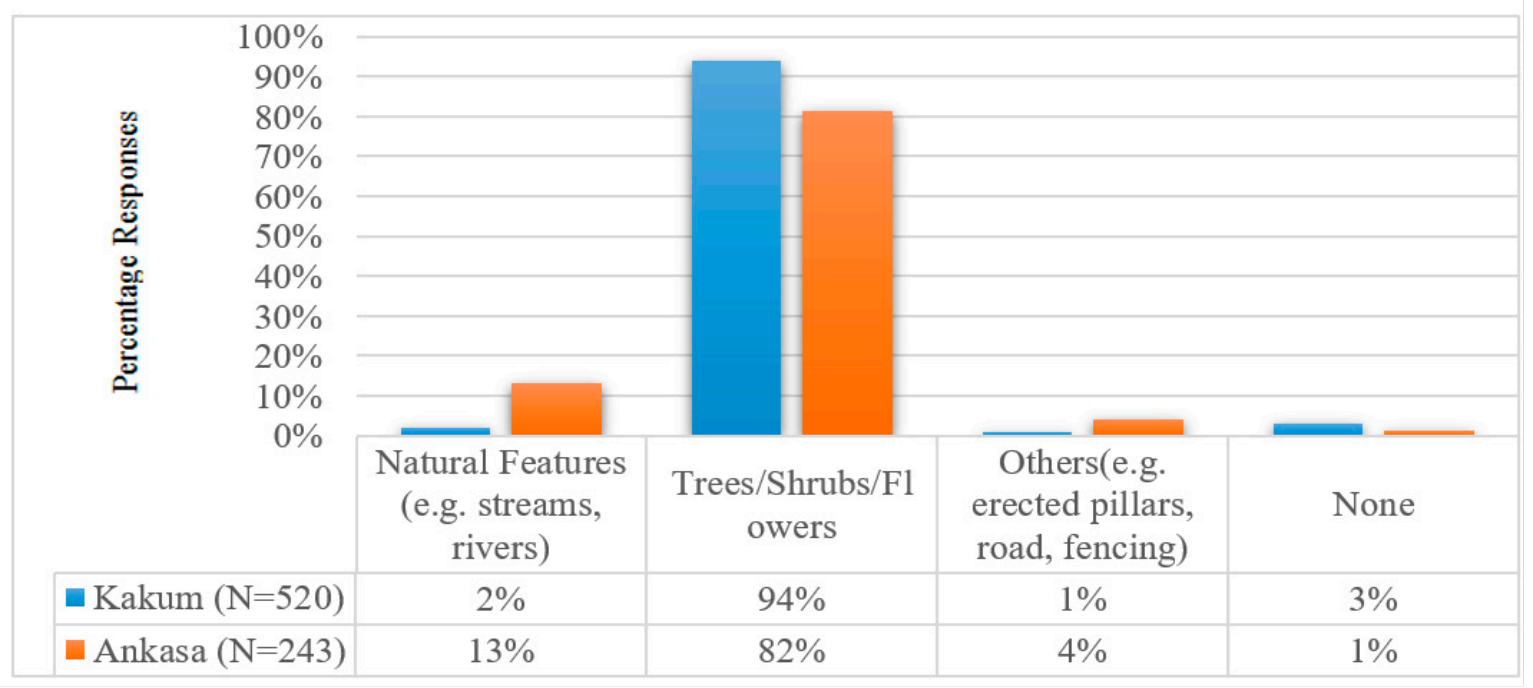

Figure 3. Type of farmland boundary indicators.

It is evident from Figure 3 that non-permanent indicators were commonly used in farmland boundary demarcations as opposed to permanent boundary indicators such as cadastral plans/maps. This finding is unsurprising to the extent that the lack of permanent and accurate boundary indicators has been identified as constituting a major source of land-related disputes associated with the insecurity and uncertainty of rural landholders property rights $[37,53,54]$. During the field interviews, the national LAP coordinator emphasised the importance of permanent boundary demarcations pointing to on-going exercises (i.e., Customary Land Demarcation and Rural Parcels Rights Demarcation projects) aimed at mapping the extent of land rights and boundaries at the community and household levels to improve the certainty and security of tenure ${ }^{5}$. While this remains necessary, it is also instructive to note that such exercises could lead to a situation of possible winners and losers, especially in rural communities where land disputes are common. For instance, the permanent boundary demarcation process could be manipulated in favour of powerful and socially connected local actors in terms of further consolidating their land claims (in the case of contested lands) to the detriment of vulnerable actors like women and the poor. It may also result in some natives losing their entitlements (social right) to land, whereas strangers may have an opportunity to bolster the security of their (de facto) land rights, which otherwise would have been difficult to accomplish [55]. In any case, the authority of chiefs (as custodians and administrators of customary lands) also comes into play here. Social groups lacking recognition from chiefs could lose their de facto land rights (particularly third-party migrant transfers without appropriate legitimation by traditional authorities), whereas those of persons recognised by the chiefs might more likely be protected in the event of any conflicting land claims occasioned by such permanent farmland demarcation exercises [56]. To the extent that the foregoing holds true, this could perhaps result in heightened tensions and social insecurity in said communities (see Section 4.1). This inference derives support from Kasanga and Kotey's [39] and Ayee et al.'s [54] observations that the inefficiency and complicity that plague state land agencies renders them susceptible to manipulations by a few powerful actors (including chiefs and local elites) to the detriment of the less powerful and poor majority. The foregoing also finds expression in Lund's [55] statement that 'the process of securing land rights can often become complex when several

5 At the time of the fieldwork, the Rural Parcels Rights Demarcation (RPRD) project had taken off on a pilot basis in the western, Ashanti and Brong Ahafo regions, focusing on demarcating 5118 farmlands in the afore-mentioned regions. 
competing normative orders may be brought to bear to legitimize specific claims'. In this view, looser demarcations might actually reduce disputes relative to permanent precise measurements when interested parties might start to contest boundaries if they perceive they might permanently lose out particularly in conflict-prone communities. This further underlines the relevance of a sufficient understanding of the local socio-political realities as a precursor and a basis for intervention programmes geared towards enhancing the certainty of rural land rights.

\subsection{Dispute Resolution Pathways and Resolution Preference}

Despite the different categories of land-related disputes in the study areas, they did not translate into widespread tenure insecurity. The field data suggest that the mechanisms for dispute resolution were largely localised within the socio-political system, with very little variation between the study sites (Table 3). From Table 3, the overall results show that traditional courts (including clan/family heads (Abusuapanyins)) and stool land offices were the main adjudicatory institutions utilised by respondents. On face value, this seems to indicate that several fora were opened to landholders in terms of the enforcement and legitimation of their land rights. Critically, however, this does not reflect the actual situation on the ground, which is seemingly complex and negotiated exemplified by opportunism and the elite capture of the adjudicatory process. Indeed, the quantitative analysis demonstrates statistically significant differences regarding access to dispute resolution institutions across studied groups. For instance, when asked whether they had ever sought help from traditional authorities or statutory courts in the resolution of land-related disputes, a far less proportion of respondents in Kakum (11\%) and Ankasa (10\%) indicated they had made recourse to the traditional authorities or statutory courts regarding the resolution of land-related disputes (Table 3). This observation was corroborated during the interviews as participants explained that in the event of land disputes, they preferred private resolution through negotiation moderated by the Abusuapanyins and/or Odikro ${ }^{6}$ at first instance. In the failure of such private resolution, recourse was made to any of the above-identified institutions.

Table 3. Mechanisms for land dispute adjudication.

\begin{tabular}{|c|c|c|c|c|c|c|}
\hline \multirow{3}{*}{$\begin{array}{c}\text { Have You Sought Help with Land } \\
\text { Dispute Resolution? }\end{array}$} & \multicolumn{3}{|c|}{ Kakum Region } & \multicolumn{3}{|c|}{ Ankasa Region } \\
\hline & \multicolumn{2}{|c|}{ Ethnicity } & \multirow{2}{*}{$\begin{array}{c}\text { Total } \\
(N=232)\end{array}$} & \multicolumn{2}{|c|}{ Ethnicity } & \multirow{2}{*}{$\begin{array}{c}\text { Total } \\
(N=148)\end{array}$} \\
\hline & $\begin{array}{l}\text { Indigene } \\
(n=17)\end{array}$ & $\begin{array}{l}\text { Migrant } \\
(n=215)\end{array}$ & & $\begin{array}{l}\text { Indigene } \\
(n=40)\end{array}$ & $\begin{array}{l}\text { Migrant } \\
(n=108)\end{array}$ & \\
\hline Yes & $12 \%$ & $11 \%$ & $11 \%$ & $10 \%$ & $9 \%$ & $10 \%$ \\
\hline No & $88 \%$ & $89 \%$ & $89 \%$ & $90 \%$ & $91 \%$ & $91 \%$ \\
\hline \multicolumn{7}{|l|}{ Institutional preference } \\
\hline Traditional court & $100 \%$ & $98 \%$ & $98 \%$ & $98 \%$ & $88 \%$ & $91 \%$ \\
\hline Statutory court & 0 & $1 \%$ & $1 \%$ & $2 \%$ & $2 \%$ & $2 \%$ \\
\hline Stool land office & 0 & $1 \%$ & $1 \%$ & 0 & 0 & 0 \\
\hline Don't know & 0 & 0 & 0 & 0 & $10 \%$ & $7 \%$ \\
\hline
\end{tabular}

Whereas Table 3 demonstrates a limited recourse to adjudicatory mechanisms, there is a sense of trust in the mediation afforded by traditional authorities as opposed to statutory institutions. During the community FGDs, participants cited the inaccessibility, delays in adjudication, cost, public image and fear of being labelled vexatious litigant as the reasons for their preference traditional dispute resolution mechanisms. These customary mechanisms played a pivotal role in maintaining social cohesion in their communities, particularly as most disputing parties are relatives or neighbours in the same village. Traditional authorities (who interpret and administer custom) were well-versed with the

6 Odikro is the village chief or headman in the Akan traditional areas of southern Ghana. 
local customs, norms and rules governing communal landholdings and thus more capable of dealing with contestations over land use and ownership. Two typical remarks by key informants are illustrative of the above observation:

'Most people prefer an amicable settlement of their land-related disputes by making recourse to the Odikro and his elders as opposed to the court. This is due to several reasons, including the fact that the courts are expensive, delays in going to and fro and the fear of being labelled a litigant, which could affect or strain social relationships between families and friends in the community...'. (Interview 1, Kakum)

'In this community we see ourselves as one, and as such, we try to resolve any disputes, especially in relation to land, amongst ourselves, sometimes even without seeking help from Odikro and his elders. Neglect of the customary structures could attract some scorn and/or sanctions from other members of the community ...' .' (Interview 1, Kakum)

The overwhelming stated preference for traditional adjudicatory mechanisms relative to the statutory courts in the study areas also finds expression in the observation that institutional constraints and allegations of corruption impede the effective functioning of the state courts as secure avenues for the protection of land rights irrespective of social status $[39,57,58]$. Indeed, interviews with some officials of the stool land office and CLS revealed that the local populace were quite sceptical that the statutory mechanisms would best serve their interests and/or protect their land rights as powerful entities could influence decisions in their favour. This is indicative of Platteau's [57] remark that 'in social contexts dominated by differential access to state administration [as in Ghana's case], there is always the fear that the adjudication/registration process will be manipulated by the elite to its advantage'. At the same time, the foregoing also brings to the fore an important question as to the effectiveness of these customary mechanisms in the protection of land rights of different social groups. This is discussed within the context of the respondents' satisfaction with the customary adjudicatory mechanisms.

\subsubsection{Satisfaction with Local Dispute Resolution Mechanisms}

Given that respondents in both study areas expressed a high preference for traditional over statutory mechanisms of land dispute resolution, it was instructive to further ascertain the extent to which respondents perceived customary mechanisms to be effective in land dispute resolution. Respondents were therefore asked about whether they were satisfied with the local dispute mechanisms in their respective communities, the results of which are shown in Tables 4 and 5.

Table 4. Satisfaction with local dispute resolution mechanisms by ethnicity.

\begin{tabular}{|c|c|c|c|c|c|c|}
\hline \multirow{3}{*}{$\begin{array}{c}\text { Are You Satisfied with the Local Dispute } \\
\text { Resolution Mechanisms? }\end{array}$} & \multicolumn{3}{|c|}{ Kakum Region } & \multicolumn{3}{|c|}{ Ankasa Region } \\
\hline & \multicolumn{2}{|c|}{ Ethnicity } & \multirow{2}{*}{$\begin{array}{c}\text { Total } \\
(N=232)\end{array}$} & \multicolumn{2}{|c|}{ Ethnicity } & \multirow{2}{*}{$\begin{array}{c}\text { Total } \\
(N=148)\end{array}$} \\
\hline & $\begin{array}{c}\text { Indigene } \\
(n=17)\end{array}$ & $\begin{array}{l}\text { Migrant } \\
(n=215)\end{array}$ & & $\begin{array}{l}\text { Indigene } \\
(n=40)\end{array}$ & $\begin{array}{l}\text { Migrant } \\
(n=108)\end{array}$ & \\
\hline Yes & $65 \%$ & $74 \%$ & $73 \%$ & $83 \%$ ** & $57 \%$ ** & $64 \%$ \\
\hline No & $35 \%$ & $25 \%$ & $26 \%$ & $17 \%$ & $14 \%$ & $15 \%$ \\
\hline Don't know & 0 & $1 \%$ & $1 \%$ & 0 & $29 \%$ & $21 \%$ \\
\hline
\end{tabular}

\footnotetext{
** significant at $p \leq 0.05$;
} 
Table 5. Satisfaction with local dispute resolution mechanisms by gender.

\begin{tabular}{|c|c|c|c|c|c|c|}
\hline \multirow{3}{*}{$\begin{array}{l}\text { Are You Satisfied with the Local Dispute } \\
\text { resolution Mechanism? }\end{array}$} & \multicolumn{3}{|c|}{ Kakum Region } & \multicolumn{3}{|c|}{ Ankasa Region } \\
\hline & \multicolumn{2}{|c|}{ Gender } & \multirow{2}{*}{$\begin{array}{c}\text { Total } \\
(N=232)\end{array}$} & \multicolumn{2}{|c|}{ Gender } & \multirow{2}{*}{$\begin{array}{c}\text { Total } \\
(N=148)\end{array}$} \\
\hline & $\begin{array}{c}\text { Male } \\
(n=197)\end{array}$ & $\begin{array}{l}\text { Female } \\
(n=35)\end{array}$ & & $\begin{array}{c}\text { Male } \\
(n=123)\end{array}$ & $\begin{array}{l}\text { Female } \\
(n=25)\end{array}$ & \\
\hline Yes & $75 \%$ & $66 \%$ & $73 \%$ & $63 \%$ & $68 \%$ & $64 \%$ \\
\hline No & $24 \%$ & $34 \%$ & $26 \%$ & $15 \%$ & $16 \%$ & $15 \%$ \\
\hline Don't Know & $1 \%$ & 0 & $1 \%$ & $22 \%$ & $16 \%$ & $21 \%$ \\
\hline
\end{tabular}

From Table 4, it is quite clear that respondents were generally satisfied with the customary dispute resolution mechanisms in the study areas. In Ankasa, however, a comparatively lower proportion of migrants $(57 \%)$ as against indigenes $(83 \%)$ expressed satisfaction with traditional adjudicatory mechanisms $\left(p<0.05 ; \chi^{2}=8.01\right)$, which perhaps suggests their waning confidence in traditional authorities as impartial arbiters in land dispute resolution. Corroborating this assertion is a typical remark by a migrant farmer in Ankasa:

'If you are a settler farmer here and you have an issue over land with a Nzema [indigene], it is likely that the decision by the traditional authorities would favour your opponent due to his ethnicity. In the eyes of the chiefs, you, the stranger, cannot profess stronger ties to the land than the indigene as you only came to make a living ...' '.(Interview 1, Ankasa, June 2015)

Elsewhere in south-western Ghana, Boone and Duku [59] and Boni [60] reported the incidence of landlord-migrant disputes ostensibly aggravated by local adjudicatory mechanisms operating to favour native landlords at the expense of migrant-tenant farmers.

\subsubsection{Gendered Dimensions of Dispute Resolution Preference}

Despite the overwhelming preference for customary adjudicatory mechanisms, the results do not necessarily imply that there is complete trust (in terms of fairness and transparency of the procedures employed) in them (Tables 4 and 5). As evidenced in Table 5, the disaggregated results suggest that traditional adjudicatory mechanisms are not entirely immune from gender biases. Indeed, the qualitative interviews highlighted instances of alleged discrimination where traditional authorities used their power to subvert justice, especially in favour of powerful actors within the local political hierarchy and indigenes in the event of contestations with migrant farmers. In the case of women, for example, focus group discussants argued to the effect that customary mechanisms were somewhat discriminatory (gender-biased) to the extent that women even had to rely on spouses and male relatives to enforce their land rights in the event of any contestations. In most of the surveyed communities, it was socially unacceptable (taboo) for women to discuss land matters with strangers without prior approval of their male relatives or husbands. Interestingly, they were equally unenthused about the statutory court as a forum for enforcement of their property rights, citing a myriad of reasons, including fear of possible backlash by the community for not according respect to traditional authorities, marital tensions, leading to instability of marriage, and poverty.

It is inferable from the above-enumerated reasons that fear of community sanctions and poverty perhaps constitute the underlying reasons for respondents' preference for the customary mechanisms and not necessarily because of equity in the adjudicatory processes. The low levels of education could also be a potential barrier to the enforcement of land rights via the formal adjudicatory mechanisms, especially in the case of women (in rural areas) who might be intimidated by the formal procedures that characterise the state courts [61]. This observation is supported by the fact that a far lesser proportion of respondents in Kakum (28\%) and Ankasa (7\%) who had sought help from either the customary and/or statutory dispute resolution mechanisms were women. The peculiar vulnerability of women is witnessed in the fact they generally constitute the largest segment 
of the poor, with limited access to requisite financial resources and education, particularly in the rural areas. Yet, the statutory mechanisms, as observed earlier, are touted as expensive and bureaucratic, which invariably implies that seeking enforcement or protection of land rights within such mechanisms could well be outside the reach of the poor and vulnerable. To the extent that this inference is correct, it is not totally surprising that the majority of respondents prefer traditional courts as a forum to assert their land rights notwithstanding issues of discrimination and procedural inequities (both perceived and real) that may characterise customary mechanisms.

In spite of a low preference for the formal mechanisms of dispute resolution, interviews with officials of the Assin Fosu Municipal Court revealed that land-related cases constituted the highest number of cases registered, although official/exact figures were not readily available. Further enquiries at the Assin Fosu and Elubo stool land offices showed that these offices were playing an unconventional role acting as forums for the resolution of land disputes (through mediation) involving farmers and landowners, especially in communities within their jurisdictional scope. It can therefore be concluded that whereas several options are available to landholders as forums for enforcement and protection of their land rights, in practice, they have restricted options, as evidenced by the above-enumerated challenges plaguing the existing mechanisms for dispute resolution. As pointed out by Rao [62], 'Legal pluralism does not imply a normative preference of one legal order or the other, as the choice of the arena for contestation is ultimately a political choice, determining as it does the access to resources.' Thus, the different identities, subject positions (within the local socio-political hierarchy), authority and fairness of procedures used could be instrumental in determining final outcomes $[17,62]$.

\section{Conclusions and Policy Implications}

This study examined the extent to which customary land dispute resolution mechanisms are fit for purpose in contemporary tenurial relations in rural Ghana. This is against the backdrop of increasing contestations over customary land, exacerbated by land commercialisation and commodification. Yet, the burgeoning scholarship has largely focused on large-scale land-grabbing and inter-community boundary disputes, with relatively little empirical attention to intra-community dynamics on traditional land dispute resolution processes [31-33]. The findings of this study demonstrate that despite concerns about the exclusionary practices in the customary land delivery process [9,49,51], traditional institutions remain the preferred fora for land dispute resolution in the surveyed communities. The overwhelming preference of traditional mechanisms for land dispute resolution rather than state courts ( $98 \%$ and $90 \%$ of respondents in Kakum and Ankasa, respectively) is a testament of the strong social legitimacy enjoyed by local customary tenure arrangements regarding land dispute resolution. For instance, reasons adduced by respondents for the high stated preference for traditional dispute resolution mechanisms included accessibility, in-depth knowledge of local tenurial issues by traditional authorities, inexpensive and expeditious settlement of disputes and public image (see Section 4.3). It therefore follows that traditional dispute resolution mechanisms can be supported and strengthened (particularly in terms of procedural equity and enforcement of decisions) as way of facilitating their integration into the statutory dispute resolution system.

In furtherance to this, efforts initiated under the auspices of the recently ended Land Administration Project (LAP) in collaboration with the Ghana Judicial Service to support the creation of Customary Land Secretariat (CLS) internal dispute resolution forums through alternative dispute resolution (ADR) are encouraging and should be up-scaled. In doing so, however, it is important to take cognizance of the myriad of local level challenges including protracted chieftaincy disputes and multiple claims to land that could stifle the harmonisation process (see Section 4). For example, with the existing contestations over land ownership at the paramountcy level in parts of Ankasa and Kakum, there is the underlying tendency that the government's move of ceding greater control over customary land in traditional authorities (through the CLS concept) as part of the 
broader agenda of strengthening customary tenure institutions could further escalate these disputes (Section 4.3). Besides, a lack of permanent land boundaries and the undocumented nature of land rights also have a propensity to trigger (latent) land disputes and perhaps the loss of land rights of the poor and vulnerable social groups, especially in the wake of growing land scarcity and commodification [8].

This calls for the speedy resolution of chieftaincy disputes and conflicts over allodial ownership, land boundary demarcation and recordation of land rights as critical first steps towards improving certainty of land ownership in the study areas. Moreover, the existing power imbalances vis-à-vis the increasing monetisation of access arrangements have created seeming spaces for the manipulation and abuse of chiefly authority to the detriment of the poor and vulnerable social groups in the study areas [8]. This thus suggests that addressing issues such as transparency, accountability and fairness in customary decisions regarding land use and allocative decision-making is crucial to ensure efficient customary land delivery and safeguard the interests of the poor and vulnerable social groups [63]. Within this context, the legally mandated CLS (under the recently promulgated Lands Act 2020) provides a basis where some personnel and local women leaders may be trained as community volunteer paralegals to provide local support mechanisms for women and other vulnerable groups seeking to enforce their land rights in both customary and statutory spheres.

Furthermore, traditional authorities may be trained in these areas (under the auspices of the traditional councils, regional and national Houses of Chiefs and the Ministry of Chieftaincy and Culture) to ensure fairness in their administration of land and dispute settlement. At the same time, it is recommended that socially disadvantaged groups, including women, migrants and the youth, be allocated seats on the village land management committees to give a voice to these groups and sufficient consideration of their interests in land allocation. An encouraging sign that this could be achieved in Ankasa and Kakum is that a few migrant settlers in some communities have been elevated to the position of village headmen. Besides, adopting such an inclusive stance in the composition of local land management committees could foster institutional trust and possibly dispel any misconceptions of the CLS being a collusion between government and traditional authorities to usurp the land rights of rural landholders. The creation of a permanent gender desk under the CLS would also provide useful support and protection of land rights of women and other marginalised groups. Equally important is the need to review the excessive concentration of power in traditional authorities under the existing regulatory framework on customary land administration to safeguard against potential abuse of authority and discrimination. One way to achieving this end would perhaps be the codification of existing customary rules and norms on land allocation and use in different traditional areas to afford clarity and unbiased interpretation as well as minimise their susceptibility to manipulation by traditional authorities. This is, however, a very complex issue, considering that the codification has the propensity to fossilise fluid customary norms, thereby limiting their flexibility [63-65]. Besides, the fact that land matters are politically sensitive sitting at the cleavage of national politics and tradition in Ghana vis-à-vis the government's policy of non-interference highlights the need for a cautious approach to legal reforms in this direction. Navigating this dilemma thus requires serious political willingness on the part of government and traditional authorities in facilitating the creation of more neutral policy spaces for these sensitive yet important issues to be deliberated amongst politicians, representatives of the regional and national Houses of Chiefs and civil society groups at large. Academia also has an important role to play in continuously undertaking independent evidence-based research to inform policy deliberations and actions, particularly on questions regarding who benefits and who loses from efforts on harmonising traditional and statutory adjudicatory mechanisms in customary land governance.

This study is not without limitations. The cross-sectional nature of the dataset has meant that important differences and tenurial changes over time that might affect land dispute dynamics could not be explored. It is recognised that the use of household panel 
data will afford an opportunity to capture effects of tenurial changes on local dispute resolution mechanisms and preferences over time rather than cross-sectional variation only. A related issue has to do with the limited interpretability of the findings, as they might be subject to self-reported recall bias. The generalisability of the survey findings to other contexts with varying socio-economic and tenurial characteristics, particularly northern Ghana, should be with caution. Nevertheless, the combination of qualitative and survey data (especially information obtained through key informant interviews and focus group discussions) afforded a unique opportunity to sufficiently explain and capture some local-level nuances in local dispute resolution pathways and preferences, which otherwise would have remained unobserved or hidden in a wholly quantitative study.

Funding: The manuscript writing was supported through the Natural Environment Research Council award number NE/R016429/1 as part of the UK-SCAPE programme delivering National Capability.

Institutional Review Board Statement: The research was carried out as part of larger DPhil study titled "Land Tenure and Sustainable Land Use in Rural Ghana", which was approved by the Central University Research and Ethics Committee (CUREC) of the University of Oxford in 2013.

Informed Consent Statement: Participation in this research was voluntary and all participants gave their full prior-informed verbal and written consent before the conduct of the interviews and household survey. The collated data from the survey and interviews were duly anonymised using de-identifiers or pseudonyms to safeguard the confidentiality of participants.

Data Availability Statement: The datasets generated and/or analysed during the present study are not publicly available in order to protect the privacy of participants but are available from the corresponding author on reasonable request.

Acknowledgments: The author would like to thank Gideon Tuffour and Godfred Bempah for research assistance. We are grateful to the traditional leaders and community members of the Kakum and Ankasa regions and other research participants for their contributions to the research process. We also express our gratitude to the anonymous reviewers and other colleagues at Oxford for their valuable comments and suggestions on earlier drafts of this article. All remaining errors are the author's own.

Conflicts of Interest: The author declares no conflict of interest.

\section{References}

1. Union, African. Land Policy in Africa: A Framework to Strengthen Land Rights, Enhance Productivity and Secure Livelihoods; African Union and Economic Commission for Africa: Addis Ababa, Ethiopia, 2009. Available online: https://bit.ly/3a1IFkc (accessed on 23 January 2021).

2. FAO. State of the World's Forest; FAO: Rome, Italy, 2012. Available online: http://www.fao.org/3/i3010e/i3010e.pdf (accessed on 23 January 2021).

3. Byamugisha, F. Securing Land Tenure and Easing Access to Land. In Background Paper for African Transformation Report 2016: Transforming Africa's Agriculture; African Center for Economic Transformation (ACET): Accra, Ghana, 2016; pp. 1-34.

4. Ghebru, H.H.; Edeh, H.; Ali, D.; Deininger, K.; Okumo, A.; Woldeyohannes, S. Tenure Security and Demand for Land Tenure Regularization in Nigeria. 2014. Available online: https:/ / bit.ly /3sRYT8k (accessed on 23 January 2021).

5. Knight, R.S. Statutory Recognition of Customary Land Rights in Africa: An Investigation into Best Practices for Lawmaking and Implementation. FAO Legislative Study 105. 2010. Available online: http:/ /www.fao.org/3/i1945e/i1945e00.pdf (accessed on 23 January 2021).

6. Deininger, K.W. Land Policies for Growth and Poverty Reduction; World Bank Publications: Washington, DC, USA, 2003; Available online: https: / / bit.ly/39d1W2Q (accessed on 23 January 2021).

7. Owusu Ansah, B.; Chigbu, U.E. The Nexus between Peri-Urban Transformation and Customary Land Rights Disputes: Effects on Peri-Urban Development in Trede, Ghana. Land 2020, 9, 187. [CrossRef]

8. Asaaga, F.A.; Hirons, M.A. Windows of opportunity or windows of exclusion? Changing dynamics of tenurial relations in rural Ghana. Land Use Policy 2019, 87, 104042. [CrossRef]

9. Akaateba, M.A. The politics of customary land rights transformation in peri-urban Ghana: Powers of exclusion in the era of land commodification. Land Use Policy 2019, 88, 104197. [CrossRef]

10. Crook, R.C. State Courts and the Regulation of Land Disputes in Ghana: The Litigants' Perspective. 2005. Available online: https:/ / www.ids.ac.uk/download.php?file=files/Wp241.pdf (accessed on 23 January 2021). 
11. Baah, K.; Kidido, J.K. Sharecropping arrangement in the contemporary agricultural economy of Ghana: A study of Techiman North District and Sefwi Wiawso Municipality, Ghana. J. Plan. Land Manag. 2020, 1, 50-62.

12. Yaro, J.A. Customary tenure systems under siege: Contemporary access to land in Northern Ghana. GeoJournal 2010, 75, 199-214. [CrossRef]

13. UN (United Nations). Global Sustainable Development Report. 2015. Available online: https://bit.ly/3sTQkKi (accessed on 23 January 2021).

14. Augustinus, C. Comparative Analysis of Land Administration Systems: African Review; The World Bank: Washington, DC, USA, 2003; Available online: https: / bit.ly/3iHoZq0 (accessed on 23 January 2021).

15. Bromley, D.W. Formalising property relations in the developing world: The wrong prescription for the wrong malady. Land Use Policy 2009, 26, 20-27. [CrossRef]

16. Peters, P.E. Conflicts over land and threats to customary tenure in Africa. Afr. Aff. 2013, 112, 543-562. [CrossRef]

17. Crook, R.C. Customary Justice Institutions and Local Alternative Dispute Resolution: What Kind of Protection Can They Offer to Customary Landholders. Contesting Land and Custom in Ghana: State, Chief and the Citizen. 2008, pp. 131-154. Available online: https:/ / bit.ly/3iE79nu (accessed on 23 January 2021).

18. Antwi-Agyei, P.; Dougill, A.J.; Stringer, L.C. Impacts of land tenure arrangements on the adaptive capacity of marginalized groups: The case of Ghana's Ejura Sekyedumase and Bongo districts. Land Use Policy 2015, 49, 203-212. [CrossRef]

19. Robinson, J.A.; Acemoglu, D. Why Nations Fail: The Origins of Power, Prosperity and Poverty; Profile: London, UK, 2012.

20. Byamugisha, F.F.K. Securing Africa's Land for Shared Prosperity: A Program to Scale up Reforms and Investments; The World Bank: Washington, DC, USA, 2013; Available online: https:/ / bit.ly/2KGcY7s (accessed on 23 January 2021).

21. Onoma, A.K. The Politics of Property Rights Institutions in Africa; Cambridge University Press: Cambridge, UK, 2009.

22. Asaaga, F.A. Land Rights, Tenure Security and Sustainable Land Use in Rural Ghana. Ph.D. Thesis, University of Oxford, Oxford, $\mathrm{UK}, 2017$.

23. Bugri, J.T. Improving Land Sector Governance in Ghana; World Bank: Washington, DC, USA, 2012; Available online: https: / / bit.ly/3sRQy4f (accessed on 23 January 2021).

24. Deininger, K.; Ali, D.A.; Alemu, T. Impacts of land certification on tenure security, investment, and land market participation: Evidence from Ethiopia. Land Econ. 2011, 87, 312-334. [CrossRef]

25. Bezu, S.; Holden, S. Demand for second-stage land certification in Ethiopia: Evidence from household panel data. Land Use Policy 2014, 41, 193-205. [CrossRef]

26. Lawry, S.; Samii, C.; Hall, R.; Leopold, A.; Hornby, D.; Mtero, F. The impact of land property rights interventions on investment and agricultural productivity in developing countries: A systematic review. J. Dev. Eff. 2017, 9, 61-81. [CrossRef]

27. Adoko, J.; Akin, J.; Knight, R. Understanding and Strengthening Women's Land Rights under Customary Tenure in Uganda. Land and Equity Movement Uganda. 2011. Available online: https:/ / bit.ly/2NmyC1s (accessed on 23 January 2021).

28. Nkwae, B. Conceptual Framework Modelling and Analysing Periurban Land Problems in Southern Africa. 2006. Available online: http:/ / www2.unb.ca/gge/Pubs/TR235.pdf (accessed on 23 January 2021).

29. Akaateba, M.A.; Huang, H.; Adumpo, E.A. Between co-production and institutional hybridity in land delivery: Insights from local planning practice in peri-urban Tamale, Ghana. Land Use Policy 2018, 72, 215-226.

30. Obeng-Odoom, F. Property, Institutions, and Social Stratification in Africa; Cambridge University Press: Cambridge, UK, 2020.

31. Kansanga, M.M.; Arku, G.; Luginaah, I. Powers of exclusion and counter-exclusion: The political ecology of ethno-territorial customary land boundary conflicts in Ghana. Land Use Policy 2019, 86, 12-22. [CrossRef]

32. Biitir, S.B.; Nara, B.B. The role of Customary Land Secretariats in promoting good local land governance in Ghana. Land Use Policy 2016, 50, 528-536. [CrossRef]

33. Kuusaana, E.D.; Kidido, J.K.; Appiah, M.N.; Mireku, K.O. Alternative Dispute Resolution by Chiefs and Tendamba: A Case Study of Kumasi and Wa Traditional Areas. 2013. Available online: https:/ / bit.ly /3qIMzoU (accessed on 23 January 2021).

34. Deininger, K.; Gershon, F. Land Institutions and Land Markets. In Handbook of Agricultural Economics; Elsevier: Amsterdam, The Netherlands, 2001; Volume 1, pp. 287-331.

35. Anyidoho, N.A.; Amanquah, S.T.; Clottey, E.A. Chieftaincy Institutions and Land Tenure Security: Challenges, Responses, and the Potential for Reform; Institute of Statistical, Social \& Economic Research, University of Ghana: Accra, Ghana, 2008.

36. Cleaver, F. Reinventing institutions: Bricolage and the social embeddedness of natural resource management. Eur. J. Dev. Res. 2002, 14, 11-30. [CrossRef]

37. Ghana National Land Policy. 1999. Available online: https://www.documents.clientearth.org/library/download-info/nationalland-policy-1999/ (accessed on 23 January 2021).

38. LAP. Restructuring of the Ghana Land Administration Project; Project Paper No. 45705; LAP: Accra, Ghana, 2008.

39. Kasanga, R.K.; Kotey, N.A. Land Management in Ghana: Building on Tradition and Modernity. 2001. Available online: https: / / bit.ly/369ogbM (accessed on 23 January 2021).

40. Agbosu, L.; Awumbila, M.; Dowuona-Hammond, C.; Tsikata, D. Customary and Statutory Land Tenure and Land Policy in Ghana; Institute of Statistical Social and Economic Research (ISSER), University of Ghana: Accra, Ghana, 2007.

41. Government of Ghana. Emerging Land Tenure Issues. 2003. Available online: https://bit.ly/3c4wPbH (accessed on 23 January 2021). 
42. Bentsi-Enchill, K. Ghana Land Law, An Exposition, Analysis and Critique. Ghana Land Law, an Exposition, Analysis and Critique. 1964. Available online: https:/ / bit.ly/3pekXaL (accessed on 23 January 2021).

43. Mamdani, M. Historicizing power and responses to power: Indirect rule and its reform. Soc. Res. 1999, 66, 859-886.

44. Njoh, A.J.; Akiwumi, F. Colonial legacies, land policies and the millennium development goals: Lessons from Cameroon and Sierra Leone. Habitat Int. 2012, 36, 210-218. [CrossRef]

45. Berry, S.S. No Condition is Permanent: The Social Dynamics of Agrarian Change in Sub-Saharan Africa; University of Wisconsin Press: Madison, WI, USA, 1993.

46. De Juan, A. "Traditional" Resolution of Land Conflicts: The Survival of Precolonial Dispute Settlement in Burundi. Comp. Political Stud. 2017, 50, 1835-1868. [CrossRef]

47. Fred-Mensah, B.K. Capturing ambiguities: Communal conflict management alternative in Ghana. World Dev. 1999, 27, 951-965. [CrossRef]

48. Obeng-Odoom, F. Urban land policies in Ghana: A case of the emperor's new clothes? Rev. Black Political Econ. 2014, 41, 119-143. [CrossRef]

49. Whitehead, A.; Tsikata, D. Policy discourses on women's land rights in Sub-Saharan Africa: The implications of the re-turn to the Customary. J. Agrar. Chang. 2003, 3, 67-112. [CrossRef]

50. Tsikata, D.; Seini, W. Identities, Inequalities and Conflicts in Ghana. 2004. Available online: https://bit.ly/39SO0dG (accessed on 23 January 2021).

51. Miles, M.B.; Huberman, A.M. Qualitative Data Analysis: An Expanded Sourcebook; Sage: Thousand Oaks, CA, USA, 1994.

52. Tettey, W.; Gebe, B.Y.; Ansah-Koi, K. The Politics of Land and Land-Related Conflicts in Ghana; No. 84; Institute of Statistical, Social \& Economic Research, University of Ghana: Accra, Ghana, 2008.

53. Bugri, J.T. The dynamics of tenure security, agricultural production and environmental degradation in Africa: Evidence from stakeholders in north-east Ghana. Land Use Policy 2008, 25, 271-285. [CrossRef]

54. Ayee, J.R.; Frempong, A.K.; Asante, R.; Boafo-Arthur, K. Local Power Struggles, Conflicts and Conflict Resolution: The Causes, Dynamics and Policy Implications of Land-Related Conflicts in the Greater Accra and Eastern Regions of Ghana; CODESRIA: Dakar, Senegal, 2011.

55. Lund, C. Property and citizenship: Conceptually connecting land rights and belonging in Africa. Afr. Spectr. 2011, 46, 71-75. [CrossRef]

56. Boamah, F. How and why chiefs formalise land use in recent times: The politics of land dispossession through biofuels investments in Ghana. Rev. Afr. Political Econ. 2014, 41, 406-423. [CrossRef]

57. Platteau, J.-P. The evolutionary theory of land rights as applied to sub-Saharan Africa: A critical assessment. Dev. Chang. 1996, 27, 29-86. [CrossRef]

58. S Amanor, K.; Ubink, J.M. Contesting Land and Custom in Ghana. State, Chief and the Citizen; Leiden University Press: Leiden, The Netherlands, 2008.

59. Boone, C.; Duku, D.K. Ethnic land rights in western Ghana: Landlord-stranger relations in the democratic era. Dev. Chang. 2012, 43, 671-693. [CrossRef]

60. Boni, S. Clearing the Ghanaian Forest: Theories and Practices of Acquisition, Transfer and Utilisation of Farming Titles in the Sefwi-Akan Area; Institute of African Studies, University of Ghana: Accra, Ghana, 2005.

61. Ghana Statistical Service. Ghana Living Standards Survey Round 6 (GLSS6); Ghana Statisical Service: Accra, Ghana, 2014.

62. Rao, N. Custom and the courts: Ensuring women's rights to land, Jharkhand, India. Dev. Chang. 2007, 38, 299-319. [CrossRef]

63. Arko-Adjei, A. Adapting Land Administration to the Institutional Framework of Customary Tenure: The Case of Peri-Urban Ghana; No. 184; IOS Press: Amsterdam, The Netherlands, 2011.

64. Oba, A.A. The future of customary law in Africa. In The Future of African Customary Law; Fenrich, J., Galizzi, P., Higgins, T.E., Eds.; Cambridge University Press: Cambridge, UK, 2011.

65. Woodman, G.R. A survey of customary laws in Africa in search of lessons for the future. In The Future of African Customary Law; Fenrich, J., Galizzi, P., Higgins, T.E., Eds.; Cambridge University Press: Cambridge, UK, 2011; pp. 9-30. 